\title{
Relationships between the number of immunostaining gonadotropes and the plasma concentrations of gonadotrophins in ewes with and without the $\mathrm{FecB}^{\mathrm{B}}$ gene
}

\author{
D. A. Heath ${ }^{1}$, M. Caldani ${ }^{2}$ and K. P. McNatty ${ }^{1 *}$ \\ ${ }^{1}$ Wallaceville Animal Research Centre, Upper Hutt, New Zealand; and ${ }^{2}$ INRA, PRMD, \\ Laboratoire de Neuroendocrinologie Sexuelle, 37380 Nouzilly, France
}

\begin{abstract}
Booroola ewes possess a major gene, $F e c \mathrm{~B}^{\mathrm{B}}$, that influences their ovulation rate (number of ovulations per oestrous cycle). Homozygous (BB) carriers of the $F e c \mathrm{~B}^{\mathrm{B}}$ gene have higher plasma concentrations of FSH and sometimes $\mathrm{LH}$ relative to the non-carriers $(++)$. The aim of this study was to determine whether the plasma concentration differences in FSH or LH between the genotypes were due to a greater number of FSH $\beta$ or LHß-immunostaining cells in the anterior pituitary gland of $\mathrm{BB}$ ewes during the luteal phase of the oestrous cycle. No differences were found between the BB $(n=7)$ ewes and $++(n=8)$ ewes in total number of pituitary cells, pituitary volume, numbers or diameters of FSH $\beta$ - or LH $\beta$-immunostaining cells, notwithstanding significantly higher concentrations of immunoreactive plasma FSH $(P<0.001)$ but not $\mathrm{LH}$ in BB compared with ++ animals. Significant linear relationships were found within each genotype between plasma FSH and number of FSH $\beta$-immunostaining cells. No such relationship was found for plasma LH and number of LH $\beta$ cells. For the FSH relationship, the slopes of the regression lines were the same. It is hypothesized that the differences in plasma concentration of FSH between the genotypes is due to a greater output of FSH per pituitary cell in the $\mathrm{BB}$ animals.
\end{abstract}

\section{Introduction}

Booroola ewes possess a major gene, $F e c \mathrm{~B}^{\mathrm{B}}$, that influences their ovulation rate (for review see Montgomery et al., 1992). Homozygous $(\mathrm{BB})$, heterozygous $(\mathrm{B}+)$ and non-carriers $(++)$ of the $F e c B^{B}$ gene have ovulation rates of $\geq 5,3-4$ and $1-2$, respectively. It is known that the immunoreactive (i) and bioactive (b) plasma concentrations of FSH (and on some occasions, $\mathrm{i}-\mathrm{LH}$ concentrations) are higher in intact or ovariectomized ewes relative to ++ ewes (McNatty et al., 1987, 1989; Phillips et al., 1993). These differences between the $\mathrm{BB}$ and ++ genotypes can also be demonstrated in hypothalamic-pituitary disconnected (HPD), intact or ovariectomized ewes given identical amounts of exogenous $\mathrm{GnRH}$ (McNatty et al., 1991, 1993). The implications from these findings of $F e c B^{B}$ differences in the plasma concentrations of FSH and LH are that they are inducible by GnRH action and that they are independent of factors secreted by the gonad. Moreover, the effects on pituitary hormone release are specific to $\mathrm{GnRH}$ action, since no gene differences are observed with respect to thyroid stimulating hormone (TSH) or growth hormone $(\mathrm{GH})$ after treatment with exogenous thyroid hormone releasing hormone or growth hormone releasing hormone, respectively (McNatty et al., 1994).

*Correspondence.

Received 3 I July 1995.
The underlying reason for this difference in pituitary responsiveness to $\mathrm{GnRH}$ is not known. The $F e c \mathrm{~B}^{\mathrm{B}}$ gene has been assigned to chromosome 6 and therefore excluded from linkage to the $\mathrm{FSH} \beta$ region of chromosome 15 or the LH $\beta$ region of chromosome 14 (Montgomery et al., 1990, 1993; Penty et al., 1995). The $\mathrm{Fec} \mathrm{B}^{\mathrm{B}}$ gene does not influence the number or size of the FSH $\beta, \mathrm{LH} \beta$ or $\alpha$ gonadotrophin gene transcripts in pituitary mRNA preparations (Montgomery et al., 1990, 1993; Fleming et al., 1995). Moreover, it does not influence the median charge or half-life of FSH in intact or ovariectomized ewes (Phillips et al., 1995), the hypothalamic GnRH contents or the pituitary GnRH-binding characteristics (Fleming et al., 1990). In studies of fetal development in Booroola sheep, differences have been noted in the development of the mesonephros and germ cells in newly forming gonads (Smith et al, 1993). Similar studies on the development of pituitary gonadotropes have not been carried out.

It is possible that the differences in plasma FSH (and LH) concentrations occur because the pituitary gland in $\mathrm{BB}$ ewes contains more cells that synthesize $\beta$-FSH or co-synthesize $\beta$-FSH and $\beta$-LH but not $\alpha$-gonadotrophin when stimulated with $\mathrm{GnRH}$. The aim of the present study was to determine whether the differences between the genotypes in plasma gonadotrophin concentrations were due to a greater number of FSH- and LH-immunostaining pituitary cells in the BB genotype. 


\section{Materials and Methods}

All experiments were performed in accordance with the 1987 Animals Protection (Codes of Ethical Conduct) Regulations of New Zealand after approval was granted by the Animal Ethics Committee at the Wallaceville Animal Research Centre.

\section{Animals and blood sampling}

Pituitaries were recovered from Booroola $\times$ Merino ewes $(++, n=8$; BB, $n=7)$ after exsanguination. For the ++ and $\mathrm{BB}$ animals, respectively, the mean \pm SEM ages were $6.3 \pm 0.3$ and $6.5 \pm 0.3$ years, the mean body masses were $43.6 \pm 1.4$ and $40.9 \pm 0.8 \mathrm{~kg}$, and the mean days of the oestrous cycle when the pituitaries were recovered were $9.8 \pm 0.6$ and $9.2 \pm 0.5$.

A blood sample $(10 \mathrm{ml})$ was collected from each animal before slaughter by jugular venepuncture and the plasma was recovered and stored at $-20^{\circ} \mathrm{C}$ until assayed for either FSH or LH. Frequent samples were not taken for LH pulse analysis.

\section{Tissue preparation}

Immediately after recovery, the pituitaries were immersion fixed in a solution consisting of PBS $\left(0.1 \mathrm{~mol} \mathrm{l}^{-1}\right)$, anhydrous disodium hydrogen orthophosphate $\left(0.08 \mathrm{~mol} \mathrm{I}^{-1}\right)$, sodium dihydrogen orthophosphate dihydrate $\left(0.03 \mathrm{~mol} \mathrm{l}^{-1}\right), \mathrm{NaCl}$ $\left(0.8 \mathrm{~mol} \mathrm{l}^{-1}\right)$ containing $4 \%(\mathrm{w} / \mathrm{v})$ paraformaldehyde and $15 \%$ (v/v) aqueous saturated picric acid ("supafix", $\mathrm{pH} 7.3$ ) for $7 \mathrm{~h}$ at $4^{\circ} \mathrm{C}$. With five sheep $(++, n=3 ; \mathrm{BB}, n=2)$, the pituitaries were fixed by perfusing $20 \mathrm{l}$ of chilled $0.9 \%(\mathrm{w} / \mathrm{v})$ saline through the carotid arteries followed by a further $20 \mathrm{l}$ of "supafix". Subsequently, these pituitaries were sectioned longitudinally and immersed in "supafix" for an additional $24 \mathrm{~h}$ at $4^{\circ} \mathrm{C}$ and then transferred to Bouin-Hollandes fixative containing mercuric chloride, cupric acetate, $\left(0.11 \mathrm{~mol} \mathrm{l}^{-1}\right)$ picric acid $\left(0.15 \mathrm{~mol} \mathrm{l}^{-1}\right)$, mercuric chloride $\left(0.18 \mathrm{~mol} \mathrm{l}^{-1}\right)$ and $11.8 \%$ $(\mathrm{v} / \mathrm{v})$ formaldehyde for $24 \mathrm{~h}$ at room temperature. The pituitaries were then rinsed in running tap water for $24 \mathrm{~h}$, processed through graded alcohols and xylene and embedded in paraffin wax. Serial sections $(5 \mu \mathrm{m})$ were cut through the entire pituitary and after every fiftieth section, four consecutive pairs of sections were mounted on microscope slides coated with 3-aminopropyltriethoxysilane (Aldrich Chemical Co. Inc., WI).

\section{Pituitary hormones}

The pituitary gonadotrophin subunits, FSH $\beta$ (Batch L128302) and LH 3 (Batch L1313022), were obtained from Bioscan International Inc., St Eustache, Quebec, whereas gonadotrophin $\alpha$-subunit (AFP-13; NIAMDD and NICHD), NIADDK-oLH-26 (2.3 iu mg ${ }^{-1}$ ), NIH-TSH-S8 (1.7 iu mg ${ }^{-1}$ ), NIADDK-oTSH-12 (27 iu $\mathrm{mg}^{-1}$ ), NIH-prolactin-S13 (30 iu $\mathrm{mg}^{-1}$ ), NIH-GH-SII (0.56 iu $\mathrm{mg}^{-1}$ ) and USDA-oFSH-18 (1640 iu $\mathrm{mg}^{-1}$ ) were supplied via the National Hormone and Pituitary Program, Bethesda, MD.

\section{Antibodies}

Antisera against highly purified ovine FSH $\beta$ (Courot et al., 1984; No. 178) and pig LH $\beta$ (Dacheau and Dubois, 1978;
No. 19526) were raised in horse and rabbit, respectively. When tested in our laboratory by radioimmunoassay, the FSH $\beta$ antibody relative to FSH $\beta$ (i.e. $100 \%$ ) showed significant crossreaction with intact ovine FSH $(21 \%)$, but against the common $\alpha$ subunit of oFSH, oLH and oTSH or intact oGH, oTSH, oLH and oprolactin, all crossreactions were $<0.02 \%$. For the LH $\beta$ antibody (No. 19526), there was a significant crossreaction with intact oLH $(36 \%)$ but limited crossreactions were observed with other ovine pituitary hormones: prolactin and oFSH $(<0.02 \%)$, gonadotrophin $\alpha$ subunit $(0.3 \%)$, oGH (1.2\%) and oTSH (3.8\%).

\section{Immunocytochemistry}

An avidin-biotin immunoperoxidase technique, based on the method of Hsu et al. (1981), was used to localize FSH $\beta$ and LH $\beta$ subunits in separate sections of ovine pituitary tissue. No attempts were made to study the proportions of cells that localized both the FSH $\beta$ and LH $\beta$ subunits. Paraffin-embedded sections were deparaffinized with xylene, rehydrated through graded alcohols and endogenous peroxidase activity was quenched with exposure to $3 \%(\mathrm{v} / \mathrm{v})$ hydrogen peroxidase in methanol for $30 \mathrm{~min}$. The sections were washed $(3 \times 10 \mathrm{~min})$ in Tris- $\mathrm{HCl}$ buffer (Tris (hydroxymethyl) methylamine, $0.5 \mathrm{~mol}$ $\left.1^{-1} ; 0.9 \% \mathrm{w} / \mathrm{v} \mathrm{NaCl} ; \mathrm{pH} 7.6\right)$. Sections were then incubated with nonimmune blocking serum, diluted $1: 15$ in Tris- $\mathrm{HCl}$ buffer for 30 min to reduce nonspecific immunostaining (nonimmune goat serum and nonimmune swine serum were used for the localization of FSH $\beta$ and $\mathrm{LH} \beta$, respectively). The appropriate primary antibody (horse anti-FSH $\beta$; diluted 1:200 or rabbit anti-LH- $\beta$; diluted $1: 300$ in Tris- $\mathrm{HCl}$ buffer $+0.1 \%$ BSA (w/v; reagent grade; Immuno-chemical Products Ltd, Auckland)) was applied to the sections and they were incubated overnight at $4^{\circ} \mathrm{C}$ in a humid chamber. All other incubations and washes were performed at room temperature. The sections were then washed three times for $10 \mathrm{~min}$ each in Tris- $\mathrm{HCl}$ buffer and then incubated for $30 \mathrm{~min}$ with a second antibody, namely biotinylated goat anti-horse IgG (Pierce, Rockford, IL) for the detection of FSH $\beta$ and biotinylated swine anti-rabbit IgG (DAKOPATTS, DAKO Corporation, Carpintria, CA) for the detection of $\mathrm{LH} \beta$. Both secondary antibodies were diluted $1: 500$ in Tris- $\mathrm{HCl}$ buffer containing $0.1 \%(\mathrm{w} / \mathrm{v}) \mathrm{BSA}$ and $1 \%(v / v)$ nonimmune sheep serum. After a further three 10-min washes in Tris- $\mathrm{HCl}$ buffer, an avidin-biotinylated horseradish peroxidase complex (DAKOPATTS) was applied to the sections and they were incubated for $30 \mathrm{~min}$. The sections were given a further three 10-min washes in Tris- $\mathrm{HCl}$ buffer and the immunoperoxidase activity visualized with $3,3^{\prime}$-diaminobenzidene tetrahydrochloride $\left(0.56 \mathrm{mmol} \mathrm{l}^{-1}\right)$ in Tris-HCl buffer containing ammonium nickel sulphate (13 mmol l-1 $\mathrm{m}^{-1}, 0.002 \%(\mathrm{v} / \mathrm{v})$ hydrogen peroxidase in which the sections were incubated for $5 \mathrm{~min}$. After a final $5 \mathrm{~min}$ wash in Tris- $\mathrm{HCl}$ buffer, the sections were counterstained in eosin, dehydrated through graded alcohols and xylene and mounted under coverslips using DePeX mounting medium.

A projection microscope (NeoPromar; Leitz) was used to observe and count nuclei in cells containing immuno-FSH $\beta$ or immuno-LH $\beta$ by the presence of a clear nonstaining portion within a cell surrounded by black immunostaining. The number Downloaded from Bioscientifica.com at 04/25/2023 11:57:57PM 
of total cells in each pituitary was estimated in the same manner, using sections stained with haemotoxylin and eosin.

\section{Hormone assays}

The radioimmunoassays for FSH and $\mathrm{LH}$ were identical to those described by McNatty et al. (1989). Briefly, for FSH the radioimmunoassay kit was supplied by the National Institute of Arthritis, Metabolism and Digestive Diseases (NIAMDD), Bethesda, MD. The oFSH for iodination was NIAMDD-oFSHI-1; the oFSH reference preparation was NIAMDD-oFSH-RP1 (biopotency $\times 75 \mathrm{NIH}-\mathrm{FSH}-\mathrm{S} 1$ ); and the oFSH antiserum was NIAMDD-anti-oFSH-1 (AFP-C5288113). For LH, the iodination standard was NIDDK-oLH-l-3 (AFP9598) and the LH antiserum was raised at Wallaceville and is described by McNatty et al. (1989). The oLH reference preparation was NIAMDD-oLH-23 (biopotency $\times 2.3$ NIH-LH-ST). The minimum detectable concentration for FSH and $\mathrm{LH}$ was $0.2 \mathrm{ng}$ $\mathrm{ml}^{-1}$. All samples for each hormone were measured in one assay, and the intra-assay coefficients of variation for the internal standards were $<8 \%$ for $\mathrm{FSH}$ and $<10 \%$ for $\mathrm{LH}$.

\section{Morphometric analysis}

Pituitary volumes (Vo) were estimated by the Cavalieri principle using the formula $V o=\Sigma a h$, where $a$, determined by point counting, is the area in $\mu \mathrm{m}^{2}$ of every 50th or 100th section ( $5 \mu \mathrm{m}$ thickness) and $h$ is the distance in $\mu \mathrm{m}$ between the sections used to determine a (Gunderson, 1986).

The number of cells, $N$, was determined using the nuclear dissector method (Gunderson, 1986) using the formula:

$$
N=\frac{\Sigma C \times V o}{\Sigma a_{(c)} \times h_{(c)}}
$$

where $h_{(c)}$ is the thickness of adjacent sections in $\mu \mathrm{m}$ (in this case $h_{(c)}=5 \mu \mathrm{m}$ ) and $C$ is the number of cells exclusive to one section in a known area, $a_{(c)}$.

\section{Pituitary cell diameter}

Cell diameters were determined by capturing images of cells and measuring their average diameter using the MICROSCALE version 2.1 programme (Digithurst Ltd, Royston, Herts). Briefly, the average diameter of each cell was calculated from the mean of four measurements. Each of the four diameters intersected the centre of the nucleus. Ten cells were measured per pituitary and an average cell diameter per animal was then calculated.

\section{Statistical analyses}

The data were subjected to analysis of variance to test for differences between genotypes. Linear relationships were examined between the total pituitary cell number, pituitary volume and the number of FSH $\beta$ - or LH $\beta$-immunostaining cells. In addition, linear relationships were examined between the number of FSH $\beta$-immunostaining cells and the peripheral plasma concentrations of FSH. As LH concentrations were close to or at the detection limit of the assay, linear relationships between the number of LHß-immunostaining cells and plasma $\mathrm{LH}$ were not examined.

\section{Results}

\section{Antibody specificity}

To test the specificity of the FSH $\beta$ and $\mathrm{LH} \beta$ antibodies in the immunocytochemical procedure, increasing amounts of the pituitary hormone ( $\mathrm{LH}, \mathrm{FSH}, \mathrm{GH}$, prolactin and TSH; i.e. 0.08, $1.6,3.1,6.3,12.5 \ldots 1600 \mu \mathrm{g} \mathrm{ml}^{-1}$ ) were preincubated with the FSH $\beta$ or LH $\beta$ antibodies and applied to the tissue sections, and the amounts needed to block binding of the $\mathrm{FSH} \beta$ or $\mathrm{LH} \beta$ antibody were assessed. Relative to FSH $\beta$ ligand, a 110-fold excess of $\mathrm{oLH}, \mathrm{oGH}$, oprolactin and $\mathrm{oTSH}$ was required to block immunostaining with the $\mathrm{FSH} \beta$ antibody. Relative to LH $\beta$ ligand, a > 110-fold excess of oFSH, a 40-fold excess of oprolactin and $\mathrm{oGH}$, and an II-fold excess of oTSH were required to block immunostaining with the LH $\beta$ antibody. The absence of nonspecific staining was confirmed by replacement of the antibodies with either Tris- $\mathrm{HCl}$ buffer $+0.1 \%(\mathrm{w} / \mathrm{v}) \mathrm{BSA}$ or nonimmune rabbit serum.

\section{Numbers of FSH $\beta$ - and LH $\beta$-immunostaining pituitary cells}

The plasma concentrations of FSH and $\mathrm{LH}$, the total number of pituitary cells and the number of FSH $\beta$ and LH $\beta$ immunostaining pituitary cells with respect to Booroola genotype are shown in Table 1 . There were gene-specific differences in the plasma concentrations of FSH $(P<0.001)$ but not $\mathrm{LH}$. The plasma $\mathrm{LH}$ concentrations were not distinguishable from the detection limit (i.e. $0.2 \mathrm{ng} \mathrm{ml}^{-1}$ ) in both genotypes. No gene-specific differences were noted with respect to the total number of pituitary cells, or in the numbers immunostaining for FSH $\beta$ or LH $\beta$. There were no gene-specific differences noted for the estimated pituitary volumes (i.e., $\mathrm{BB}=224 \pm 35$ and $++=209 \pm 47 \mathrm{~mm}^{3}$ ). The ratio obtained after dividing the plasma FSH concentration by the number of FSH $\beta$ cells to provide some estimate of cell output of FSH revealed a significant difference between the genotypes (Table 1).

\section{Diameters of $F S H \beta$ - and LH $\beta$-immunostaining pituitary cells}

The mean \pm SEM diameters $(\mu \mathrm{m})$ of immunostaining cells with respect to Booroola genotype were $8.9 \pm 0.2(++)$ and $8.8 \pm 0.2(\mathrm{BB})$ for FSH $\beta$, and $9.3 \pm 0.1(++)$ and $9.2 \pm 0.2(\mathrm{BB})$ for LH $\beta$. The mean \pm SEM diameters $(\mu \mathrm{m})$ of haematoxylin and eosin staining cells with respect to genotype were $9.6 \pm 0.2$ and $9.5 \pm 0.2$, respectively; these diameters were determined without knowledge of whether the cells were gonadotropes or some other cell type. No significant differences were found $(P>0.05)$ between genotypes for each of the cell types (FSH $\beta$, LH $\beta$ or pituitary cells in general) or between cell types within genotypes.

\section{Linear relationships among pituitary volumes, numbers of} pituitary cells and plasma FSH

Some significant linear relationships were found among the number of pituitary cells, pituitary volume, numbers of 
Table 1. Plasma concentrations of FSH and numbers of pituitary cells and FSH $\beta$ - and LH $\beta$-immunostaining pituitary cells with respect to Booroola genotype

\begin{tabular}{|c|c|c|c|c|c|}
\hline \multirow{2}{*}{$\begin{array}{l}\text { Booroola } \\
\text { genotype } \\
(n)\end{array}$} & \multirow{2}{*}{$\begin{array}{c}\text { Plasma } \\
\text { concentrations } \\
\left(\mathrm{ng} \mathrm{ml}^{-1}\right) \\
\text { FSH }\end{array}$} & \multirow{2}{*}{$\begin{array}{l}\text { Total number of } \\
\text { pituitary cells } \\
\left(\times 10^{-6}\right)\end{array}$} & \multicolumn{2}{|c|}{$\begin{array}{l}\text { Number of immunostaining } \\
\text { pituitary cells }\left(\times 10^{-6}\right)\end{array}$} & \multirow{2}{*}{$\begin{array}{c}\text { Plasma FSH } \\
\text { concentration/number of } \\
\text { FSH } \beta \text { cells }\left(\mathrm{pg} \mathrm{ml} \mathrm{m}^{-1} \text { per cell) }\right.\end{array}$} \\
\hline & & & $\mathrm{FSH} \beta$ & LH $\beta$ & \\
\hline $\mathrm{BB}(7)$ & $1.88 \pm 0.07^{* * *}$ & $234 \pm 44$ & $12 \pm 1$ & $26 \pm 4$ & $166 \pm 13^{* *}$ \\
\hline$++(8)$ & $0.70 \pm 0.04$ & $229 \pm 52$ & $10 \pm 2$ & $26 \pm 7$ & $90 \pm 18$ \\
\hline
\end{tabular}

Values are means \pm SEM

The plasma LH concentrations were not distinguishable from the detection limit of the assay (i.e. $0.2 \mathrm{ng} \mathrm{ml}^{-\mathrm{I}}$ ).

$* * * P<0.001 ; * * P<0.01$ (Student's $t$ test).

Table 2. Correlation coefficients among number of pituitary cells, pituitary volume and plasma concentrations of FSH ( $\mathrm{ng} \mathrm{ml}{ }^{-1}$ ) with respect to Booroola genotype or the genotypes combined

\begin{tabular}{llllc}
\hline & & \multicolumn{2}{c}{ Genotype } & $\begin{array}{c}\text { + } \\
\text { combined }\end{array}$ \\
\cline { 3 - 4 } Dependent variable & Independent variable & ++ & BB & \\
\hline Pituitary volume & Total number of pituitary cells & $1.00^{* * *}$ & $0.99^{* * *}$ & $1.0^{* * *}$ \\
Pituitary volume & Number of LH $\beta$ cells & $0.96^{* * *}$ & $0.85^{* * *}$ & $0.93^{* * *}$ \\
Total number of pituitary cells & Number of LH $\beta$ cells & $0.96^{* * *}$ & $0.82^{*}$ & $0.92^{* * *}$ \\
Pituitary volume & Number of FSH $\beta$ cells & 0.47 & 0.52 & 0.48 \\
Total number of pituitary cells & Number of FSH cells & 0.48 & 0.58 & 0.48 \\
Plasma FSH & Number of FSH cells & $0.81^{* *}$ & $0.83^{* *}$ & 0.48 \\
\hline
\end{tabular}

Significant linear relationship: ${ }^{* *} P<0.001,{ }^{* *} P<0.01,{ }^{*} p<0.05$. The relationship between plasma LH and number of LH $\beta$ cells could not be tested as most $\mathrm{LH}$ values were not detectable.

immunostaining $\mathrm{LH} \beta$ or FSH $\beta$ cells and plasma FSH concentrations (Table 2). The relationship between the total number of pituitary cells and volume of the pituitary could be expressed by the equation $y=2.5+0.912 x$ (for both genotypes combined), where $y=$ pituitary volume $\left(\mathrm{mm}^{3}\right)$ and $x=$ number of cells $\times 10^{-6}$. The number of LH $\beta$ cells showed a significant linear relationship with the total number of pituitary cells, namely $y=1.96+0.1 x$ (for both genotypes combined) where $y=$ number of LH $\beta$ cells $\times 10^{-6}$ and $x=$ total number of pituitary cells $\times 10^{-6}$. In addition, the number of LH $\beta$ cells showed a significant linear relationship with the pituitary volume $(\mathrm{mm}$ ), namely $y=3.0+8 x$ (for both genotypes combined), where $y=$ pituitary volume $\left(\mathrm{mm}^{3}\right)$ and $x=$ number of $\mathrm{LH} \beta$ cells $\times 10^{-6}$. Comparison showed that, for any of the above relationships, the slopes of the lines between the genotypes were not significantly different (Student's $t$ test). No significant linear relationship between the number of FSH $\beta$ cells and either pituitary volume or the total number of pituitary cells was noted. However, a significant linear relationship was established between the number of FSH $\beta$ cells and the plasma FSH concentrations within the genotypes, namely $y=0.48+0.02 x(++)$ and $y=1.38+0.04 x$ (BB), where $y=$ plasma $\mathrm{FSH}$ (ng $\mathrm{ml}^{-1}$ ) and $x=$ number of FSH $\beta$ cells $\times 10^{-6}$. The slopes of these lines were not significantly different between the genotypes. However, the linear relationship was not maintained when the data for both genotypes were combined.

\section{Discussion}

The key findings from this study are that the total numbers or mean diameters of $\mathrm{FSH} \beta$ - and $\mathrm{LH} \beta$-immunostaining pituitary cells do not differ between the Booroola genotypes, notwithstanding a two-fold difference in plasma concentration of $\mathrm{FSH}$. Moreover, no differences between the genotypes were noted for the total number of pituitary cells, mean diameter of pituitary cell or for the pituitary volume. Collectively, these findings, together with results showing no differences in pituitary FSH isoforms (Robertson et al., 1984; Phillips et al., 1995) or in the circulating half-lifes $\left(t_{1 / 2}\right)$ of FSH (Fry et al., 1987; Phillips et al., 1995) raise the possibility that the concentration difference in plasma FSH between the genotypes is due to a greater output of FSH from each pituitary cell in $\mathrm{BB}$ animals.

The hypothesis that BB animals have a greater FSH output per cell relative to ++ animals is supported by results in ovariectomized HPD ewes, in which the FSH release after an i.v. dose of $\mathrm{GnRH}$ (250 ng) in BB animals was about 1.6-fold higher $(P<0.05)$ than in the ++ genotype (McNatty et al., 1991). Whether these differences in FSH output are related directly to differences in mRNA synthesis or degradation or the synthesis and stability of the FSH molecule remain to be determined. While studies using northern blot analysis reveal no obvious differences in the amounts of pituitary mRNA for FSH $\beta$ (Fleming et al., 1995), it is possible that the difference is 
too small to be detected reliably by this technique; the gene difference in plasma FSH, as detected by radioimmunoassay in GnRH-treated HPD-ovariectomized ewes, is only 1.6-fold (McNatty et al., 1991). Perhaps a more sensitive technique, such as RNase protection assay, is needed to ensure that small differences in FSH $\beta$ mRNA synthesis are not occurring. Notwithstanding this possibility, it has been shown for the HPD-ovariectomized ewe that animals homozygous for the $\mathrm{FecB}^{\mathrm{B}}$ gene had higher FSH concentrations at 10 min after an exogenous $\mathrm{GnRH}$ injection of $250 \mathrm{ng}$ compared with homozygous non-carriers (McNatty et al., 1991). This finding suggests that the $\mathrm{Fec} \mathrm{B}^{\mathrm{B}}$ difference is more likely to be due to a different per cell output of preformed hormone. Moreover, since the gene effect in plasma FSH concentration can arise without any measurable difference in pituitary content, it seems unlikely that there are differences in the stability of the FSH molecule (Montgomery et al., 1992). Future studies may need to focus on a comparison of FSH isoforms in plasma as well as in the pituitary (Phillips et al., 1995) and on in vitro systems to examine the intracellular regulation of $\mathrm{GnRH}$-induced FSH release.

The finding that there is a significant linear relationship between pituitary volume and the number of pituitary cells or number of LH $\beta$-immunostaining cells, irrespective of genotype, suggests that the changes in pituitary volume may be a consequence of a change in the total number of cells and that the number of LH $\beta$ cells is always a fixed proportion of that total number of cells. In contrast, there is no such relationship between the number of FSH $\beta$ cells and either pituitary volume or total number of cells in either genotype, suggesting that the factors determining the number of FSH $\beta$ cells are not the same as those for $\mathrm{LH} \beta$. The finding of a significant linear relationship between the number of FSH $\beta$-immunostaining cells and plasma FSH concentration for each genotype separately, and the fact that the slopes of these regression lines were not different could infer that the disappearance of FSH from the circulation is likely to be the same in both genotypes. The half-life of FSH in intact sheep is estimated to be 110 min (Akbar et al., 1973; Fry et al., 1987), whereas that for LH is $25-30 \mathrm{~min}$ (Montgomery et al., 1984). Presumably the longer half-life for FSH than for LH allows the aforementioned linear relationship between numbers of pituitary cell and plasma concentrations to be observed.

The finding that $10-12 \%$ of the total number of cells immunostained for FSH $\beta$ is similar to that reported by Thomas et al. (1993) for adult sheep. For LH $\beta$, we report that about $26 \%$ of pituitary cells immunostained positively, whereas Thomas et al. (1993) report about 16\%. Possible explanations for this discrepancy are the age, breed and reproductive status of the ewes (not defined in the Thomas et al. (1993) study), fixation procedure, antibodies used and method of counting. Our technique was based on the nuclear dissector method, whereas Thomas et al. (1993) used a random field $(\times 4)$ point counting technique of individual sections. Notwithstanding these differences in ewes, the proportions of cells immunostaining for FSH $\beta(10-12 \%)$ or $\mathrm{LH} \beta(16-26 \%)$ are substantially higher than noted in sheep fetuses during late gestation (120-140 days of gestation) or in the newborn (FSH $\beta, 1-4 \%$; LH $\beta, 3-5 \%$ ) (Messaoud-Toumi et al., 1993). This is despite the fact that the plasma concentrations of FSH and LH in late gestation or soon after birth are higher than in adult females (Smith et al., 1993; Isaacs et al., 1995). It would be of interest to determine the effects of plasma volume and also to establish whether the median charges and clearance rate of FSH and LH in fetal and neonatal sheep differ substantially from those in adult animals.

In conclusion, this study reports a significant linear relationship between the number of FSH $\beta$-immunostaining cells and the plasma concentrations of FSH for both homozygous carriers and non-carriers of the $F e c B^{\mathrm{B}}$ gene, separately. This study also reports that there are no differences between the Booroola genotypes in the number or diameter of FSH $\beta$ - or LH $\beta$-immunostaining cells. It is hypothesized that the differences in plasma concentration of FSH between the genotypes is due to a greater output of FSH per pituitary cell in the $\mathrm{BB}$ animals.

The authors thank the National Hormone and Pituitary Program and the associated agencies who generously supplied the pituitary standards, namely NICHD, NIAMDD, NIADDK and the USDA.

\section{References}

Akbar AM, Nett TM and Niswender GD (1973) Metabolic clearance and secretion rates of gonadotropins at different stages of the estrous cycle in ewes Endocrinology 94 1318-1328

Courot M, Hochereau-de Reviers, Pisselet C, Kilgour RJ, Dubois MP and Sairam MR (1984) Effect of passive immunization against ovine $\beta F S H$ on spermatogenesis in the ram. In The Male in Farm Animal Reproduction pp 75-77 Ed. M Courot. Martinus Nijhoff Publishers, Dordrecht

Dacheau F and Dubois MP (1978) LH producing cells in the ovine pituitary Cell and Tissue Research 188 449-463

Fleming JS, Lun S, Smith P and McNatty KP (1990) Pituitary binding sites for gonadotrophin-releasing hormone in Booroola Merino ewes which were non-carriers or homozygotes of the fecundity gene F Journal of Neuroendocrinology 2 601-604

Fleming JS, Greenwood PJ, Heath DA, Hudson NL, Lun S, Shaw L and McNatty KP (1995) Expression of the gonadotrophin subunit genes in sheep that were homozygous carriers or non-carriers of the Booroola fecundity gene $\mathrm{Fec}^{\mathrm{B}}$ Journal of Reproduction and Fertility 103 315-321

Fry RC, Cahill LP, Cummins JT, Bindon BM, Piper LR and Clarke IJ (1987) The half-life of follicle-stimulating hormone in ovary-intact and ovariectomized Booroola and control Merino ewes Journal of Reproduction and Fertility 81 611-615

Gunderson HJG (1986) Stereology of arbitrary particles: a review of unbiased number and size estimators and the presentation of some new ones Journal of Microscopy 143 3-45

Hsu SM, Raine L and Fanger H (1981) Use of avidin-biotin-peroxidase complex $(A B C)$ in immunoperoxidase techniques: a comparison between $\mathrm{ABC}$ and unlabelled antibody (PAP) procedures journal of Histochemistry and Cytochemistry 29 577-580

Isaacs KL, McNally KP, Condell L, Shaw L, Heath DA, Hudson NL, Littlejohn RP and Mcleod BJ (1995) Plasma FSH, LH and immunoreactive inhibin concentrations in $\mathrm{FecB}^{\mathrm{B}} / \mathrm{FecB}^{\mathrm{B}}$ and $\mathrm{FecB}^{+} / \mathrm{FecB}^{+}$Booroola ewes and rams from birth to 12 months of age Journal of Reproduction and Fertility $10389-97$

McNatty KP, Hudson NL, Henderson KM, Gibb M, Morrison L, Ball K and Smith P (1987) Differences in gonadotrophin concentrations and pituitary responsiveness to $\mathrm{GnRH}$ between Booroola ewes that were homozygous $(\mathrm{FF})$, heterozygous $(\mathrm{F}+)$ and non-carriers $(++)$ of a major gene influencing their ovulation rate Journal of Reproduction and Fertility 80 577-588

McNatty KP, Fisher M, Collins F, Hudson NL, Heath DA, Ball K and Henderson KM (1989) Differences in the plasma concentrations of FSH and LH in ovariectomized Booroola FF and ++ ewes Journal of Reproduction and Fertility 85 705-713

McNatty KP, Hudson NL, Shaw L, Condell LA, Ball K, Seah S-L and Clarke IJ (1991) GnRH-induced gonadotrophin secretion in ovariectomized Booroola 
ewes with hypothalamic-pituitary disconnection Joumal of Reproduction and Fertility 91 583-592

McNatty KP, Hudson NL, Lun S, Heath DA, Shaw L, Condell L, Phillips DJ and Clarke IJ (1993) Gonadotrophin-releasing hormone and control of ovulation rate by the $\mathrm{Fec}^{\mathrm{B}}$ gene in Booroola ewes Journal of Reproduction and Fertility 98 97-105

McNatty KP, Hudson NL, Shaw I and Moore L (1994) Plasma concentrations of $\mathrm{FSH}, \mathrm{LH}$, thyroid stimulating hormone and growth hormone after exogenous stimulation with GnRH, TRH and GHRH in Booroola ewes that are homozygous carriers or non-carriers of the $\mathrm{Fec}^{\mathrm{B}}$ gene journal of Reproduction and Fertility 102 177-183

Messaoud-Toumi LH, Taragnat C and Durand P (1993) Heterogeneity in the storage of gonadotropins in the ovine fetus and evidence for luteinizing hormone-follicle-stimulating hormone cells in the fetal pituitary Biology of Reproduction 48 1239-1245

Montgomery GW, Crosbie SF, Martin GB and Pelletier J (1984) Changes in the clearance rate of immunoreactive LH after ovariectomy in Ile-de-France ewes. In Reproduction in Sheep pp 23-25 Eds DR Lindsay and DT Pearce, Australian Wool Corporation, Canberra

Montgomery GW, Sise JA, Greenwood PJ and Fleming JS (1990) The Booroola F gene mutation in sheep is not located close to the FSH- $\beta$ gene Journal of Molecular Endocrinology 5 167-173

Montgomery GW, McNatty KP and Davis GH (1992) Physiology and molecular genetics of mutations that increase ovulation rate in sheep Endocrine Reviews 13 309-328
Montgomery GW, Crawford AM, Penty JM, Dodds KG, Ede AJ, Henry HM, Pierson CA, Lord EA, Galloway SM, Schmack AE, Swarbrick PA, Hanrahan V, Buchanan FC and Hill DF (1993) The ovine Booroola fecundity gene $\left(\mathrm{Fec}^{\mathrm{B}}\right)$ is linked to markers from a region of human chromosome $4 \mathrm{q}$ Nature Genetics 4 410-414

Penty JM, Lord EA and Montgomery GW (1995) Linkage of LHB and MAG to GPI on sheep Chromosome 14 Mammalian Genome 6 299-300

Phillips DJ, Hudson NL and McNatty KP (1993) Effects of ovariectomy and genotype on bioactive FSH in plasma and pituitary of Booroola ewes journal of Reproduction and Fertility 98 559-565

Phillips DJ, Moore LG, Hudson NL, Lun S and McNatty KP (1995) Effects of ovariectomy but not of $\mathrm{FecB}^{\mathrm{B}}$ genotype on the median charge and circulating half-life of pituitary follicle stimulating hormone isoforms of ewes Journal of Reproduction and Fertility 104 27-31

Robertson DM, Ellis S, Foulds LM, Findlay IK and Bindon BM (1984) Pituitary gonadotrophins in Booroola and control Merino sheep Journal of Reproduction and Fertility 71 189-197

Smith P, O W-S, Hudson NL, Shaw L, Heath DA, Condell L, Phillips DJ and McNatty KP (1993) Effects of the Booroola gene $\left(\mathrm{Fec}^{\mathrm{B}}\right)$ on body weight, ovarian development and hormone concentrations during fetal life Journal of Reproduction and Fertility 98 41-54

Thomas SG, McNeilly AS and Brooks AN (1993) Development of gonadotrophs and thyrotrophs in the female foetal sheep pituitary: immunocytochemical localization studies Journal of Neuroendocrinology 5 157-161 